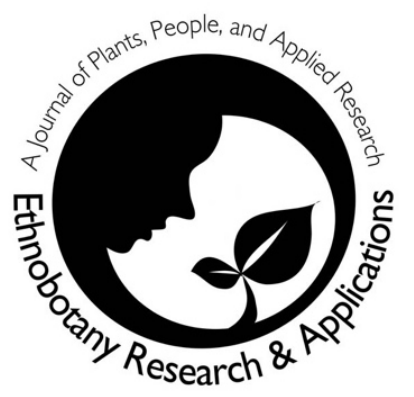

\title{
Edible and Medicinal Pteridophytes of Nepal: A Review
}

\author{
Rijan Ojha, Hari Prasad Devkota
}

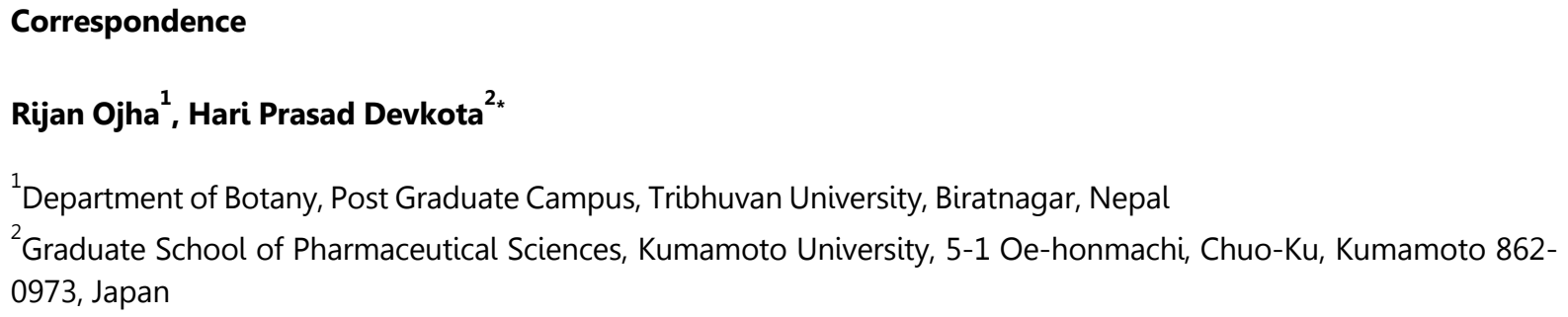

\section{Review}

\begin{abstract}
Background:Traditional use of pteridophytes as food and medicine is a common practice around the world. Many ethnic communities hold vast knowledge about the uses of pteridophytes and the documentation of such knowledge and biodiversity of edible and medicinal pteridophytes is important for health care, food security andconservation. Although being one of the biodiversity rich countries, the detailed use of edible and medicinal pteridophytes from Nepal is not well documented and they are one of the underutilized plant resources having vast potential. Thus, the aim of this review is to compile the knowledge about the use of edible and medicinal pteridophytes in Nepal.
\end{abstract}

Methods: Relevant information on traditional uses as medicinal and edible species were collected form published literatures such as research articles on ethnobotanical surveys, books, book chapters and conference proceedings.

Results: The literature survey revealed that a total of 26 species of pteridophytes were used as food and 43 species were used as traditional medicines. Among 55 useful species, 14 species were used as both food and traditional medicine. Diplazium esculentum, Diplazium maximum, Dryopteris cochleata and Ophioglossum reticulatum were commonedible species and Aleuritopteris albomarginata, Equisetum ramosissimum, Nephrolepis cordifolia and Tectaria coadunata were common medicinal pteridophytes. Most of species are growing in natural habitat and the potential utilization species were sold in the market which has also supported livelihood. Some of these pteridophytes werealso used in preparation of ethnic foods such as fermented foods and pickles.

Conclusion: Findings from the study suggested that only a few common species of pteridophytes are usedas food and traditional medicines Nepal. The knowledge about the traditional uses of pteridophytes and their biodiversity is also affected by socioeconomic changes in communities, lack of sharing of traditional knowledge through generations, improper collection practices and climate change. Very few pteridophytes from Nepal havebeen studied in detail for their phytoconstituents and biological activities and safety. Future research activities should focus on providing scientific evidence for traditional uses as well as development of proper conservation, cultivation, and product formulation methods in a sustainable manner.

Keywords: Conservation, ferns, fern allies, food security, human health 


\section{Background}

Pteridophytes are the transition group of plant between non-tracheophytes and spermatophytes. There are about 12,000 species of pteridophytes (ferns and lycophytes) found in the world (Christenhusz \& Byng 2016). They are widely used as vegetables and traditional medicines, and for landscaping and horticulture in several part of the world (Benjamin \& Manickam 2007, Ho et al. 2010, Liu et al. 2012, Minarchenko et al. 2017, Ranil \& Bussmann 2021, Sarker \& Hossain 2009). Edible pteridophytes are good sources of proteins, vitamins, crude fiber, and minerals (Chettri et al. 2018). They are rich in various phytochemicals such as steroids, terpenoids, phenolic acids and flavonoids among others. Various extracts and isolated compounds from ferns have also shown diverse biologicalactivities (Bohm \& Tryon 1967, Cao et al. 2017, Cerón-Carpio et al. 2019, Cui et al. 1993, Ho et al. 2010, Ueno et al.1963, Watanabe et al. 2021).

Nepal is a small land lock country in south Asia with vast geographical variation and rich biodiversity. Recent publication reported the existence of 582 taxa (32 families, 99 genera, 550 species and 32 subspecies) of pteridophytes in Nepal (Kandel \& Fraser-Jenkins 2020). In Nepal, ferns are distributed all over the country from east to west and low land Terai to high altitude Himalayas. Central Nepal of altitude about $2000 \mathrm{~m}$ harbors maximumspecies richness of the nation (Bhattarai et al. 2004). They are found in varied habitat like terrestrial, lithophytes,climbers, aquatic, epiphytes etc. and many ferns are also found in more than one habitat (Thakur \& Rajbhandary 2018). Three volumes of book Ferns and Fern Allies of Nepal have provided detailed account on taxonomy, distribution, threaten status of pteridophytes of Nepal (Fraser-Jenkins et al. 2015, Fraser-Jenkins \& Kandel 2019, Kandel \& Fraser-Jenkins 2020). In these books, the distribution of pteridophytes in Nepal is divided the into; lowaltitude (50-600 m), lower-mid altitude (600-1000 m), mid altitude (1000-1600 m), uppermid altitude (1600-2200m), higher altitude 2200-3000 m, high Himalayan (3000-5000 m) in elevation scale. Eastern Nepal being climatically richer zone for pteridophytes, greater numbers on distribution of pteridophytes are reported from central Nepaldue confined collections to Central Nepal and Western Nepal has the lowest number of species recorded, due to dry climate (Kandel 2020). In general, the trend of species number decreases from the east to the west with ananomaly around Pokhara, Central Nepal (Fraser-Jenkins et al. 2015). Study made by Bhattarai et al. (2004) also suggests that high mountains of Himalayas are richer in fern species than the lower plains in Nepal. Three species of fern are endemic to Nepal viz. Asplenium pseudofugax FraserJenk. \& Kandel, Bolbitis andreisii Fraser-Jenk. \&Kandel and Polystichum annapurnicola Fraser-Jenk. ex Thapa (Fraser-Jenkins et al. 2015, Fraser-Jenkins \& Kandel 2019, Kandel \& Fraser-Jenkins 2020).

There are various published articles based on the survey of medicinal and food uses of pteridophytes in the different parts of the world. For example, in China, 52 species of edible pteridophytes have been reported from ethnobotanical review (Liu et al. 2012). Similarly, 39 medicinal pteridophytes are reported from Ukraine (Minarchenko et al. 2017), 283 pteridophytes have been reported to have ethnomedicinal use in India (Sureshkumar et al. 2018), 61 medicinal pteridophytes are reported from Western Ghats of India (Benjamin \& Manickam 2007), 51 species medicinal pteridophytes are reported from North-Eastern India (Benniamin 2011), 37 pteridophytes with traditional uses (food, medicine, ornament) are reported from Sri Lanka (Ranil \& Bussmann2021), 16 pteridophytes are reported to have traditional uses in Bangladesh (Sarker \& Hossain 2009), and 36 species of medicinal pteridophytes are reported from Nigeria (Nwosu 2002).

In Nepal, many ethnic communities living in rural areas depend upon the natural resources for food and medicine in their daily life. Earlier there have been few studies undertaken to document the uses of pteridophytes in Nepal (Gurung 1979, Manandhar 1996, Tuladhar 2002). However, in recent times, no study focusing on ethnomedicinal use of pteridophytes has been reported. Although there has been significant amount of work on collection and taxonomy of pteridophytes from Nepal, not much attention has been given to their traditional useof food and medicine. Thus, the main aim of this review is to compile the knowledge about the use of edible andmedicinal pteridophytes in Nepal based on published literatures such as research articles on ethnobotanical surveys, books, book chapters and conference proceedings.

\section{Traditional uses Pteridophytes as food and medicines}

Various publications such as ethnobotanical field reports, book and conference proceedings have reported the food and medicinal uses of ferns in Nepal. The literature survey revealed that a total of 26 species of pteridophytes were used as food and 43 species were used as traditional medicines belonging to 20 families. Among them 14 species were used as both food and traditional medicine. The detailed list of these species is given in Table 1. 
Table 1. List of reported edible and/or medicinal pteridophytes from Nepal

\begin{tabular}{|c|c|c|c|}
\hline $\begin{array}{l}\text { Family } \\
\text { Scientific name } \\
\text { [Synonym] }\end{array}$ & Local Name $^{a}$ & Uses $^{\mathbf{b}}$ & Traditional uses \\
\hline \multicolumn{4}{|l|}{ Athyriaceae } \\
\hline Athyrium atkinsoni Bedd. & niuro & $\mathrm{E}$ & $\begin{array}{l}\text { The young leaf of the plant is used as vegetable } \\
\text { (Kandel 2020, Kandel \& Fraser-Jenkins 2020). }\end{array}$ \\
\hline $\begin{array}{l}\text { Athyrium strigillosum (T. } \\
\text { Moore ex Lowe) Moore ex } \\
\text { Salomon }\end{array}$ & niguro & $E$ & $\begin{array}{l}\text { The young frond of the plant is consumed as } \\
\text { vegetable by local people of Godawari, Lalitpur } \\
\text { District (Fraser-Jenkins \& Kandel 2019). }\end{array}$ \\
\hline $\begin{array}{l}\text { Deparia boryana (Willd.) M. } \\
\text { Kato } \\
\text { [Dryoanthyrium boryanum } \\
\text { (Willd.) Ching] }\end{array}$ & $\begin{array}{l}\text { kalo neuro, kali } \\
\text { niguro, liuro, } \\
\text { niuro, dhengan } \\
\text { (Tamang) }\end{array}$ & $E / M$ & $\begin{array}{l}\text { Tender shoots are used as food (Joshi \& Joshi 2008, } \\
\text { Rijal 2011, Rokaya et al. 2010). } \\
\text { Root paste is applied externally to cure burns, injury, } \\
\text { and wounds (Rokaya et al. 2010). Tender shoots are } \\
\text { given in dysentery and rhizome is used in abdominal } \\
\text { spasm (Rijal 2011). Leaf is used as medicine (Singh } \\
\text { 2015). }\end{array}$ \\
\hline $\begin{array}{l}\text { Diplazium esculantum } \\
\text { (Retz.) Sw. ex Schrader }\end{array}$ & $\begin{array}{l}\text { pani neuro, } \\
\text { niguro, masino } \\
\text { neuro, kuturke }\end{array}$ & $E / M$ & $\begin{array}{l}\text { Tender shoot or fronds are consumed as vegetables } \\
\text { (Joshi et al. 2007, Manandhar 2002, Ojha \& Niroula } \\
\text { 2021, Uprety et al. 2012). } \\
\text { Rhizomes are used in the treatment of scabies and } \\
\text { boils (Manandhar 2002), used as medicine (Bhagat \& } \\
\text { Shrestha 2010), the paste of leaf and stem is applied } \\
\text { externally in treatment of cuts and wounds (Bhattarai } \\
\text { \& Khadka 2016). }\end{array}$ \\
\hline $\begin{array}{l}\text { Diplazium kawakamii } \\
\text { Hayata }\end{array}$ & niuro & $E$ & $\begin{array}{l}\text { Tender shoots are used as vegetable (Kandel 2020, } \\
\text { Fraser-Jenkins \& Kandel 2019). }\end{array}$ \\
\hline $\begin{array}{l}\text { Diplazium maximum (D. } \\
\text { Don) C. Chr. }\end{array}$ & neuro & $\mathrm{E} / \mathrm{M}$ & $\begin{array}{l}\text { Tender shoots are used as vegetable (Joshi et al. } \\
\text { 2007, Rana et al. 2015). } \\
\text { Young shoots are taken during stomach problem } \\
\text { (Rana et al. 2015). }\end{array}$ \\
\hline $\begin{array}{l}\text { Diplazium spectabile (Wall. } \\
\text { ex Mett.) Ching }\end{array}$ & neuro & $E$ & $\begin{array}{l}\text { Tender shoots are used as vegetable (Joshi et al. } \\
\text { 2007). }\end{array}$ \\
\hline Diplazium stoliczkae Bedd. & $\begin{array}{l}\text { kalo niuro, } \\
\text { neuro, } \\
\text { kalinyuro, } \\
\text { bhandhengan } \\
\text { (Tamang) }\end{array}$ & $E / M$ & $\begin{array}{l}\text { Tender shoots are used as vegetable (Joshi et al. } \\
2007, \text { Rokaya et al. 2010, Shrestha \& Dhillion 2006). } \\
\text { The Juice of the tender leaf is given in treatment of } \\
\text { diarrhea and dysentery (Malla \& Chhetri 2009). The } \\
\text { paste of roots is applied externally for the treatment } \\
\text { of burns, injury, and wounds (Rokaya et al. 2010). }\end{array}$ \\
\hline \multicolumn{4}{|l|}{ Blechnaceae } \\
\hline $\begin{array}{l}\text { Stenochlaena palustris } \\
\text { (Burm. f.) Bedd }\end{array}$ & & $E$ & $\begin{array}{l}\text { Young shoots are used as vegetables (Kandel 2020, } \\
\text { Kandel \& Fraser-Jenkins 2020). }\end{array}$ \\
\hline \multicolumn{4}{|l|}{ Cyatheaceae } \\
\hline $\begin{array}{l}\text { Cyathea spinulosa Wall. ex } \\
\text { Hook. }\end{array}$ & $\begin{array}{l}\text { chattre, rukh } \\
\text { uniyu, thulo } \\
\text { uniyu }\end{array}$ & $E / M$ & $\begin{array}{l}\text { Young shoots of the plant are cooked as vegetable } \\
\text { (Bhattarai \& Khadka 2016, Kandel 2020). } \\
\text { Young leaf of the plant is taken orally during } \\
\text { excessive bleeding in menstruation (Bhattarai \& } \\
\text { Khadka 2016); the decoction of soft pith prepared in } \\
\text { ghee is taken orally during fracture and body ache } \\
\text { (Adhikari et al. 2019). }\end{array}$ \\
\hline \multicolumn{4}{|l|}{ Davalliaceae } \\
\hline $\begin{array}{l}\text { Davallia pulchra D. Don. } \\
\text { [Araiostegia pulchra (D. } \\
\text { Don.) Copel., Katoella }\end{array}$ & mariesii & $M$ & $\begin{array}{l}\text { Rhizome juice is taken orally to get relieve from body } \\
\text { pain and to cool down the body temperature (Malla } \\
\text { 2018). }\end{array}$ \\
\hline
\end{tabular}




\begin{tabular}{|c|c|c|c|}
\hline \multicolumn{4}{|l|}{$\begin{array}{l}\text { pulchra (D. Don.) Fraser- } \\
\text { Jenk., Kandel \& Pariyar] }\end{array}$} \\
\hline \multicolumn{4}{|l|}{ Dennstaedtiaceae } \\
\hline $\begin{array}{l}\text { Dennstaedtia } \\
\text { appendiculata (Wall. ex } \\
\text { Hook.) J. Sm. }\end{array}$ & $\begin{array}{l}\text { lute sottar, } \\
\text { masino unyu, } \\
\text { shyaula tamda } \\
\text { (Tamang) }\end{array}$ & M & $\begin{array}{l}\text { The juice of the fronds is applied to cuts (Shrestha \& } \\
\text { Joshi 1993). }\end{array}$ \\
\hline \multicolumn{4}{|l|}{ Dryopteridaceae } \\
\hline $\begin{array}{l}\text { Dryopteris cochleata (D. } \\
\text { Don) C. Chr. }\end{array}$ & $\begin{array}{l}\text { niguro, danthe } \\
\text { neuro, rani } \\
\text { neuro, lotah } \\
\text { niuro, unyau, } \\
\text { dhengan } \\
\text { (Tamang) }\end{array}$ & $\mathrm{E} / \mathrm{M}$ & $\begin{array}{l}\text { Tender shoots are used as vegetable (Joshi et al. } \\
\text { 2007, Joshi et al. 2015). } \\
\text { Leaf juice is used to treat muscular and rheumatic } \\
\text { pain (Joshi \& Joshi 2008). } \\
\text { Young shoots are used as medicine (Aryal et al. 2009). }\end{array}$ \\
\hline $\begin{array}{l}\text { Dryopteris splendens } \\
\text { (Hook. ex Bedd.) Kuntze }\end{array}$ & danthe neuro & $E$ & $\begin{array}{l}\text { The plant is used as vegetable in Dhahran, Eastern } \\
\text { Nepal (Shrestha \& Rai 2012). }\end{array}$ \\
\hline $\begin{array}{l}\text { Polystichum squarrosum } \\
\text { (D. Don) Fée }\end{array}$ & $\begin{array}{l}\text { phusre neuro, } \\
\text { thulo neuro }\end{array}$ & $\mathrm{E}$ & $\begin{array}{l}\text { The tender shoots are consumed as vegetable (Joshi } \\
\text { et al. 2007, Joshi \& Joshi 2008, Shrestha \& Dhillion } \\
\text { 2006). }\end{array}$ \\
\hline \multicolumn{4}{|l|}{ Equisetaceae } \\
\hline Equisetum arvense $\mathrm{L}$. & $\begin{array}{l}\text { kurkure, } \\
\text { middho } \\
\text { (Tamang) }\end{array}$ & M & $\begin{array}{l}\text { The paste of roots is applied on wounds caused by } \\
\text { thrones (Shrestha 1988). The whole plant with } \\
\text { rhizome is used as medicine (Budha-Magar et al. } \\
\text { 2020). }\end{array}$ \\
\hline $\begin{array}{l}\text { Equisetum ramosissimum } \\
\text { Desf. }\end{array}$ & $\begin{array}{l}\text { akhle jhaar, } \\
\text { harjor talchama } \\
\text { (Newari), } \\
\text { thongachhe } \\
\text { (Tamang) }\end{array}$ & M & $\begin{array}{l}\text { The paste made from pounded dried plant is applied } \\
\text { in bone fracture (Joshi et al. 2011). Tamang tribes of } \\
\text { Makwanpur District apply ash of the whole plant for } \\
\text { the treatment of scabies and burns (Joshi, 2014). }\end{array}$ \\
\hline \multicolumn{4}{|l|}{ Gleicheniaceae } \\
\hline $\begin{array}{l}\text { Diplopterygium giganteum } \\
\text { (Wall. ex Hook. \& Bauer) } \\
\text { Nakai } \\
\text { [Gleichenia gigantea Wall. } \\
\text { ex Hook.] }\end{array}$ & hade unyu & M & $\begin{array}{l}\text { The paste of the leaf is applied externally in the } \\
\text { treatment of cuts and wounds (Bhattarai \& Khadka } \\
\text { 2016, Joshi et al. 2011). }\end{array}$ \\
\hline \multicolumn{4}{|l|}{ Lindsaeaceae } \\
\hline $\begin{array}{l}\text { Odontosoria chinensis (L.) } \\
\text { J. Sm. subsp. chinensis } \\
\text { [Sphenomeris chinensis (L.) } \\
\text { Maxon] }\end{array}$ & $\begin{array}{l}\text { amaaro (Majhi), } \\
\text { rato unyu, } \\
\text { saano unyu }\end{array}$ & $M$ & $\begin{array}{l}\text { The powder of leaf is inhaled to cure sinusitis } \\
\text { (Shrestha \& Joshi 1993). The paste of leaves is rubbed } \\
\text { in the body swelling and feet sprain (Malla et al. } \\
\text { 2015). }\end{array}$ \\
\hline \multicolumn{4}{|l|}{ Lycopodiaceae } \\
\hline $\begin{array}{l}\text { Lycopodiella cernua (L.) Pic. } \\
\text { Serm }\end{array}$ & sano nagbeli & M & Whole plant is used as medicine (Malla 2018). \\
\hline $\begin{array}{l}\text { Lycopodium japonicum } \\
\text { Thunb. }\end{array}$ & $\begin{array}{l}\text { nagbeli, } \\
\text { banmala }\end{array}$ & M & $\begin{array}{l}\text { The paste of the spore is used in cuts, wounds, boils, } \\
\text { and cracked heels (Joshi 2014). }\end{array}$ \\
\hline \multicolumn{4}{|l|}{ Lygodiaceae } \\
\hline $\begin{array}{l}\text { Lygodium flexuosum (L.) } \\
\text { Sw. }\end{array}$ & $\begin{array}{l}\text { lahare unyu, } \\
\text { janai laharo }\end{array}$ & $\mathrm{E} / \mathrm{M}$ & $\begin{array}{l}\text { Tender shoots of the plant are used as vegetable } \\
\text { (Bhattarai 2020). } \\
\text { Plant ash is used to treat herpes (Dangol 2008). } \\
\text { Whole plant is used in treatment of sprain, fracture, } \\
\text { cuts and wound (Bhattarai 2020). }\end{array}$ \\
\hline
\end{tabular}




\begin{tabular}{|c|c|c|c|}
\hline $\begin{array}{l}\text { Lygodium japonicum } \\
\text { (Thunb.) Sw. }\end{array}$ & $\begin{array}{l}\text { janai laharo, } \\
\text { lute jhar, pinse } \\
\text { (Tamang), } \\
\text { Ukuse jhar } \\
\text { (Magar), } \\
\text { parewavuri } \\
\text { (Tamang, } \\
\text { Bankaria) }\end{array}$ & $\mathrm{E} / \mathrm{M}$ & $\begin{array}{l}\text { Young leaves are used as vegetable (Joshi \& Siwakoti } \\
\text { 2012). } \\
\text { Whole plant is used as medicine (Joshi et al. 2007, } \\
\text { Luitel et al. 2014). Juice of the plant is applied in } \\
\text { wound, boils and scabies, and the paste of the plant } \\
\text { is applied to treat joints pain (Malla et al. 2015, } \\
\text { Manandhar 1995a). }\end{array}$ \\
\hline \multicolumn{4}{|l|}{ Marsileaceae } \\
\hline Marsilea quadrifolia L. & charpate behuli & $\mathrm{E}$ & $\begin{array}{l}\text { Tender shoots are used as vegetable (Joshi \& Joshi } \\
\text { 2009). }\end{array}$ \\
\hline \multicolumn{4}{|l|}{ Nephrolepidaceae } \\
\hline $\begin{array}{l}\text { Nephrolepis cordifolia (L.) } \\
\text { C. Presl } \\
\text { [Nephrolepis auriculata (L.) } \\
\text { A. Rich] }\end{array}$ & $\begin{array}{l}\text { pani amala, } \\
\text { bhui amala, ras } \\
\text { amala, ambeli } \\
\text { (Tamang), pani } \\
\text { saro (Majhi) }\end{array}$ & $\mathrm{E} / \mathrm{M}$ & $\begin{array}{l}\text { Tuberous roots are eaten (Luitel et al. 2014, Rijal } \\
\text { 2011, Uprety et al. 2011). } \\
\text { Tuberous root juice is used to treat fever, indigestion, } \\
\text { cough, cold and headache (Aryal et al. 2009, Dhami } \\
\text { 2008). The paste of leaf is used in itching; tuberous } \\
\text { roots are eaten to cure hypertension and } \\
\text { inflammation (Malla et al. 2015). Root paste is used to } \\
\text { treat jaundice, boils, bone fracture and skin problems } \\
\text { (Pradhan et al. 2020). }\end{array}$ \\
\hline \multicolumn{4}{|l|}{ Oleandraceae } \\
\hline $\begin{array}{l}\text { Oleandra wallichii (Hook.) } \\
\text { C. Presl }\end{array}$ & jibre unyu & M & $\begin{array}{l}\text { The paste of rhizome is applied to forehead to relieve } \\
\text { headache and in cases of bone dislocation \& fracture } \\
\text { (Malla 2018). }\end{array}$ \\
\hline \multicolumn{4}{|l|}{ Ophioglossaceae } \\
\hline $\begin{array}{l}\text { Botrychium lanuginosum } \\
\text { Wall. ex Hook. \& Grev.) }\end{array}$ & $\begin{array}{l}\text { jaluko, } \\
\text { bayakhra }\end{array}$ & $\mathrm{E} / \mathrm{M}$ & $\begin{array}{l}\text { Shoots are also cooked as vegetable (Joshi et al. } \\
2007 \text {, Singh 2015). } \\
\text { The root paste is applied in treatment of boils on the } \\
\text { tongue and applied on the forehead to relieve } \\
\text { headache (Manandhar 1995b). Shoots are used in } \\
\text { body ache (Singh 2015). }\end{array}$ \\
\hline Botrychium lunaria (L.) Sw. & harre jha & M & $\begin{array}{l}\text { Paste of the plant is applied in treatment of boils and } \\
\text { cooked plants are prescribed to convalescent patients } \\
\text { as a tonic (Bhattarai 1992). }\end{array}$ \\
\hline $\begin{array}{l}\text { Botrychium multifidum } \\
\text { Trevis }\end{array}$ & $\begin{array}{l}\text { ruprecht, } \\
\text { bayakhara }\end{array}$ & M & $\begin{array}{l}\text { The paste of root is applied on forehead to relieve } \\
\text { headache; also used in treatment of blemishes on } \\
\text { tongue (Manandhar 1986). }\end{array}$ \\
\hline $\begin{array}{l}\text { Helminthostachys zeylanica } \\
\text { (L.) Hook. }\end{array}$ & $\begin{array}{l}\text { majur goda } \\
\text { (Chepang) }\end{array}$ & $\mathrm{E}$ & Tender shoots are used as vegetable (Rijal 2011). \\
\hline $\begin{array}{l}\text { Ophioglossum petiolatum } \\
\text { Hook. }\end{array}$ & jibre sag & $\mathrm{E} / \mathrm{M}$ & $\begin{array}{l}\text { Fronds are used vegetable (Kandel 2020). } \\
\text { The leaf is used to control bleeding from nose (Singh } \\
\text { 2015). }\end{array}$ \\
\hline $\begin{array}{l}\text { Ophioglossum reticulatum } \\
\text { L. }\end{array}$ & $\begin{array}{l}\text { ek patiya } \\
\text { (Tharu), } \\
\text { jibre dhap } \\
\text { (Tamang) } \\
\end{array}$ & $\mathrm{E}$ & $\begin{array}{l}\text { Leaves are used as vegetable (Bhagat \& Shrestha } \\
\text { 2010, Dangol 2008, Joshi et al. 2007, Uprety et al. } \\
\text { 2012). }\end{array}$ \\
\hline \multicolumn{4}{|l|}{ Osmundaceae } \\
\hline Osmunda claytoniana $\mathrm{L}$. & & $\mathrm{E}$ & $\begin{array}{l}\text { Leaves are used as vegetable in Dhunche, Rasuwa } \\
\text { District (Joshi et al. 2007). }\end{array}$ \\
\hline \multicolumn{4}{|l|}{ Polypodiaceae } \\
\hline $\begin{array}{l}\text { Drynaria propinqua (Wall. } \\
\text { ex Mett.) }\end{array}$ & $\begin{array}{l}\text { uneu, hadjoda, } \\
\text { kammari (Majhi } \\
\text { and Magar) }\end{array}$ & M & $\begin{array}{l}\text { Rhizome paste is used in treatment of backache and } \\
\text { dislocated bone (Malla et al. 2015, Tamang et al. } \\
\text { 2017). It is also used to cure sprains and applied on } \\
\text { forehead to get relieve from headache (Malla et al. } \\
\text { 2015). }\end{array}$ \\
\hline
\end{tabular}




\begin{tabular}{|c|c|c|c|}
\hline $\begin{array}{l}\text { Drynaria quercifolia (L.) J. } \\
\text { Sm. }\end{array}$ & thatuma (Rai) & $M$ & $\begin{array}{l}\text { The rhizome and frond paste are used in treatment of } \\
\text { cuts, wounds and infections by Rai tribes of Pathari } \\
\text { Municipality, Eastern Nepal (From author } \\
\text { observation). }\end{array}$ \\
\hline $\begin{array}{l}\text { Lepisorus bicolor(Takedal) } \\
\text { Ching }\end{array}$ & dhule uniu & $M$ & $\begin{array}{l}\text { A teaspoonful of leaf juice is taken orally twice a day } \\
\text { (for } 3-4 \text { days) in the treatment of rheumatic pains } \\
\text { (Bhattarai 1989). }\end{array}$ \\
\hline $\begin{array}{l}\text { Lepisorus mehrae Fraser- } \\
\text { Jenk. }\end{array}$ & bispech & $M$ & $\begin{array}{l}\text { The plant is used in gastrointestinal disorders (Uprety } \\
\text { et al. 2010). The powder of rhizome is used to treat } \\
\text { back pain, stomach problems and fever (Pradhan et } \\
\text { al. 2020). }\end{array}$ \\
\hline $\begin{array}{l}\text { Lepisorus thunbergianus } \\
\text { (Kaulf.) Ching }\end{array}$ & unyu & $M$ & $\begin{array}{l}\text { Gurung tribes Parbat district uses juice of the plant, } \\
\text { orally in the treatment of urinary tract infections, } \\
\text { bacterial dysentery, chronic bronchitis, and } \\
\text { rheumatism (Malla 2018). }\end{array}$ \\
\hline $\begin{array}{l}\text { Loxogramme involuta (D. } \\
\text { Don) C. Presl }\end{array}$ & parpare & $M$ & $\begin{array}{l}\text { Gurung tribes Parbat district uses rhizome juice } \\
\text { externally to treat cuts and wounds (Malla 2018). }\end{array}$ \\
\hline $\begin{array}{l}\text { Polypodiodes amoena } \\
\text { (Wall. ex Mett) Ching }\end{array}$ & bhiespaj & $M$ & $\begin{array}{l}\text { Rhizome is used as medicine and sold in the streets } \\
\text { of Kathmandu (Author's observation). }\end{array}$ \\
\hline \multicolumn{4}{|l|}{ Pteridaceae } \\
\hline $\begin{array}{l}\text { Adiantum capillus-veneris } \\
\text { L. }\end{array}$ & pakhale unyu & M & $\begin{array}{l}\text { Leaf paste is used in headaches and chest pain; } \\
\text { decoction of plant is taken in the treatment of } \\
\text { whooping cough, throat, and bronchitis problems } \\
\text { (Joshi \& Joshi 2008). The whole plant is used as } \\
\text { medicine (Bhagat \& Shrestha 2010). Leaf paste is } \\
\text { applied externally in cuts to prevent bleeding (Singh } \\
\& \text { Hamal 2013). Root juice is taken in migraine, snake } \\
\text { bite and scorpion bite (Kunwar et al. 2008). A paste of } \\
\text { plant is applied to the forehead to relieve headache } \\
\text { and to chest to relieve chest pain. Juice of frond is } \\
\text { mixed with honey and used for the treatment of } \\
\text { cough (Manandhar 2002). }\end{array}$ \\
\hline Adiantum caudatum $\mathrm{L}$. & $\begin{array}{l}\text { uneu, ratijar, } \\
\text { daluko, dan } \\
\text { sinki, seto } \\
\text { sinki, twasilwa } \\
\text { (Tamang) }\end{array}$ & $M$ & $\begin{array}{l}\text { About four tablespoons of decoction prepared from } \\
\text { plant is given twice a day in case of gastric troubles } \\
\text { (Manandhar 1993). Juice of the rhizome is used for } \\
\text { the treatment of fever and indigestion (Manandhar } \\
\text { 2002). Green leaves are used in skin infection, } \\
\text { decoction of dried leaves is used for the treatment of } \\
\text { cough and fever. Leaf juice is used for the treatment } \\
\text { of diabetes (Joshi \& Joshi 2008). }\end{array}$ \\
\hline Adiantum incisum Forssk. & & $M$ & $\begin{array}{l}\text { Frond juice is used to cure scabies (Joshi \& Joshi } \\
\text { 2008). The fronds are used as medicine (Bhagat } \& \\
\text { Shrestha 2010). }\end{array}$ \\
\hline $\begin{array}{l}\text { Adiantum philippense } \mathrm{L} \text {. } \\
\text { [Adiantum lunulatum } \\
\text { Burm. f.] }\end{array}$ & & M & $\begin{array}{l}\text { The whole plants are used as medicine (Bhagat \& } \\
\text { Shrestha 2010). }\end{array}$ \\
\hline $\begin{array}{l}\text { Adiantum venustum } \mathrm{D} . \\
\text { Don }\end{array}$ & daluko & M & $\begin{array}{l}\text { Paste of rhizome is used in cuts and wounds } \\
\text { (Manandhar 2002). }\end{array}$ \\
\hline $\begin{array}{l}\text { Aleuritopteris } \\
\text { albomarginata (C.B. Clarke) } \\
\text { Ching } \\
\text { [Cheilanthes albomarginata } \\
\text { C.B. Clarke, Cheilanthes } \\
\text { dalhousiae Hook] }\end{array}$ & $\begin{array}{l}\text { damini sinka, } \\
\text { dankernu, } \\
\text { dumni sinka, } \\
\text { rani sinka, } \\
\text { kalising } \\
\text { (Sherpa), } \\
\text { duwane sinka } \\
\text { (Tharu) }\end{array}$ & $M$ & $\begin{array}{l}\text { The juice of the leaves is used for the treatment of } \\
\text { stomachache (Uprety et al. 2011). Two to three table } \\
\text { spoons of frond juice is taken in treatment of gastritis } \\
\text { (Thapa 2012). Rai tribes of Bhojpur District eat raw } \\
\text { frond of the plant during snake bite (Rai \& Singh } \\
\text { 2015). The powder of rhizome is used to treat } \\
\text { gastritis and stomach problems (Rana et al. 2015, } \\
\text { Pradhan et al. 2020). The paste of the leaves is }\end{array}$ \\
\hline
\end{tabular}




\begin{tabular}{|c|c|c|c|}
\hline & & & $\begin{array}{l}\text { applied in cuts and wounds (Budha-Magar et al. } \\
\text { 2020). }\end{array}$ \\
\hline $\begin{array}{l}\text { Aleuritopteris anceps } \\
\text { (Blanf.) Panigrahi } \\
\text { [Cheilanthes anceps Blanf.] }\end{array}$ & ranisinka & M & $\begin{array}{l}\text { Juice of the plant mixed with that of Drymaria diandra } \\
\text { is used for peptic ulcer (Manandhar 2002). The shoots } \\
\text { are used in abdominal spasm and wound (Rijal 2011). } \\
\text { The leaf and stem of plant is boiled and consumed } 3 \\
\text { times a day to cure case of stomach problems (Ambu } \\
\text { et al. 2020). }\end{array}$ \\
\hline $\begin{array}{l}\text { Aleuritopteris bicolor } \\
\text { (Roxb.) Fraser-Jenk. } \\
\text { [Cheilanthes bicolor } \\
\text { Forssk.] }\end{array}$ & $\begin{array}{l}\text { dankernu, rani } \\
\text { sinka }\end{array}$ & M & $\begin{array}{l}\text { The powder of whole plant is taken orally in sinusitis } \\
\text { and applied in fever and cuts (Luitel et al. 2014, } \\
\text { Tamang et al. 2017). The juice of the plant is taken } \\
\text { during diarrhea, dysentery, and gastritis (Adhikari et } \\
\text { al. 2019). }\end{array}$ \\
\hline $\begin{array}{l}\text { Aleuritopteris rufa (D. Don) } \\
\text { Ching } \\
\text { [Cheilanthes rufa D. Don.] }\end{array}$ & $\begin{array}{l}\text { kane sinka, dub } \\
\text { khando }\end{array}$ & M & $\begin{array}{l}\text { The juice of rhizome and frond is used in treatment of } \\
\text { abdominal disorders, cuts, and wounds (Dhami 2008) }\end{array}$ \\
\hline $\begin{array}{l}\text { Ceratopteris thalictroides } \\
\text { (L) Brongn }\end{array}$ & $\begin{array}{l}\text { dhaniya jhar, } \\
\text { pani dhaniya }\end{array}$ & $\mathrm{E} / \mathrm{M}$ & $\begin{array}{l}\text { Tender shoots are used as vegetables (Dangol 2008, } \\
\text { Joshi \& Joshi 2009). } \\
\text { The leaves and roots are used as a poultice against } \\
\text { skin complaints (Bhatt et al. 2021). }\end{array}$ \\
\hline $\begin{array}{l}\text { Oeosporangium } \\
\text { tenuifolium (Burm.f.) } \\
\text { Fraser-Jenk. \& Pariyar } \\
\text { [Cheilanthes teunifolia } \\
\text { (Burm. f.) Sw.] }\end{array}$ & kaali sinkaa & M & $\begin{array}{l}\text { The paste of frond is applied on abscesses in the } \\
\text { form of poultice to remove pus (Singh \& Hamal } \\
\text { 2013). The rhizome and roots of the plant is used as } \\
\text { general tonic, anthelminthic for asthma (Bhatt et al. } \\
\text { 2021). }\end{array}$ \\
\hline $\begin{array}{l}\text { Pteris aspericaulis Wall. ex } \\
\text { J. Agardh }\end{array}$ & mauro & M & $\begin{array}{l}\text { The paste of rhizome is applied in treatment of cuts, } \\
\text { boils, and muscular swellings; the peeled rhizome } \\
\text { fried in clarified butter is eaten for effective treatment } \\
\text { backache (Manandhar 1990). Juice of rhizome is used } \\
\text { in diarrhea and dysentery (Manandhar 2002). }\end{array}$ \\
\hline Pteris biaurita L. & $\begin{array}{l}\text { dantheniuro, } \\
\text { haaade unyu, } \\
\text { kuthurke (Raji) }\end{array}$ & $\mathrm{E} / \mathrm{M}$ & $\begin{array}{l}\text { Young leaves are consumed as vegetable by Raji } \\
\text { tribes in western Nepal (Thapa et al. 2014). Newar, } \\
\text { Chhetri, Tamang and Bankaria communities of } \\
\text { Makawanpur District occasionally uses as wild } \\
\text { vegetable (Joshi \& Siwakoti 2012). } \\
\text { The paste of frond is applied in treatment of cuts and } \\
\text { wounds (Manandhar 2002). The Magar tribes of Palpa } \\
\text { District uses leaves of the plant in cuts and wounds } \\
\text { (Ale et al. 2009). }\end{array}$ \\
\hline \multicolumn{4}{|l|}{ Tectariaceae } \\
\hline $\begin{array}{l}\text { Tectaria coadunata (Wall. } \\
\text { ex Hook. \& Grev.) C. Chr. } \\
\text { [Tectaria macrodonta (Fée) } \\
\text { C. Chr.] }\end{array}$ & $\begin{array}{l}\text { niuro, kalo } \\
\text { neuro, kalo } \\
\text { kuthurke, } \\
\text { toplign degni } \\
\text { (Tamang) }\end{array}$ & $\mathrm{E} / \mathrm{M}$ & $\begin{array}{l}\text { The young leaves are used as vegetables (Aryal et al. } \\
\text { 2009, Dangol 2008, Joshi et al. 2007, Joshi et al. 2015, } \\
\text { Luni et al. 2011) } \\
\text { Root juice is used to treat diarrhea and dysentery } \\
\text { (Adhikari et al. 2019). About } 6 \text { tablespoon of rhizome } \\
\text { juice twice a day for } 4 \text { days is given in case of gastric } \\
\text { trouble (Manandhar 1995a). }\end{array}$ \\
\hline \multicolumn{4}{|l|}{ Thelypteridaceae } \\
\hline $\begin{array}{l}\text { Thelypteris nudata (Roxb.) } \\
\text { C.V. Morton } \\
\text { [Thelypteris multilineata } \\
\text { (Wall. ex Hook.) Morton] }\end{array}$ & koche & $\mathrm{E}$ & Young shoots are used as vegetables (Joshi et al. 2007). \\
\hline
\end{tabular}

Photographs of some of these species are included in Figures 1-4. Pteridaceae is the largest family of pteridophytes with traditional uses (13 species) followed by Athyriaceae (8 species). According to Ferns and Fern Allies of Nepal 
Vol. 1-3, Dryopteridaceae (110 species) is the largest family of pteridophytes in Nepal followed by Pteridaceae (92 species) in Nepal. Pteridaceae is also reported as the largest family of traditionally used species in India (Sureshkumar et al. 2018).

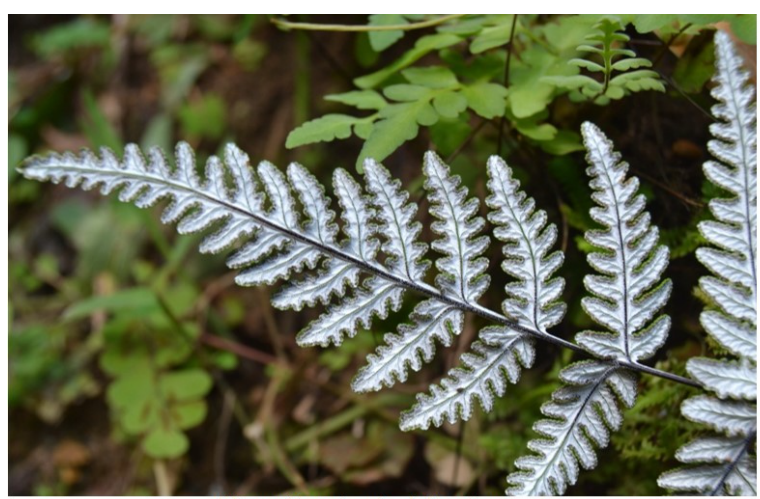

Aleuritopteris bicolor

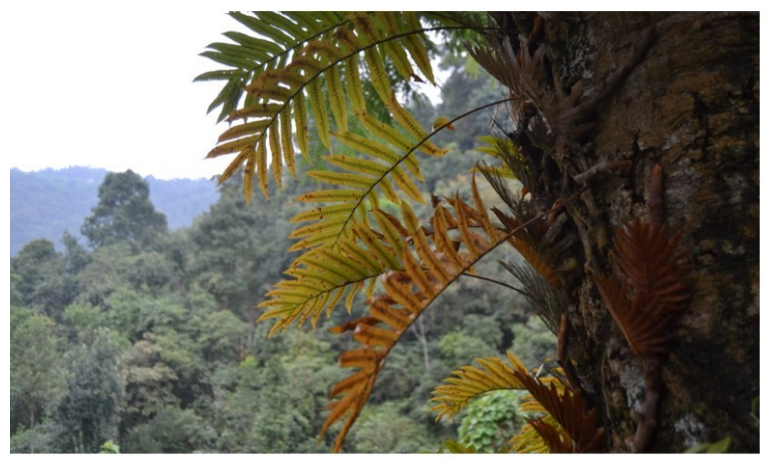

Drynaria propinqua

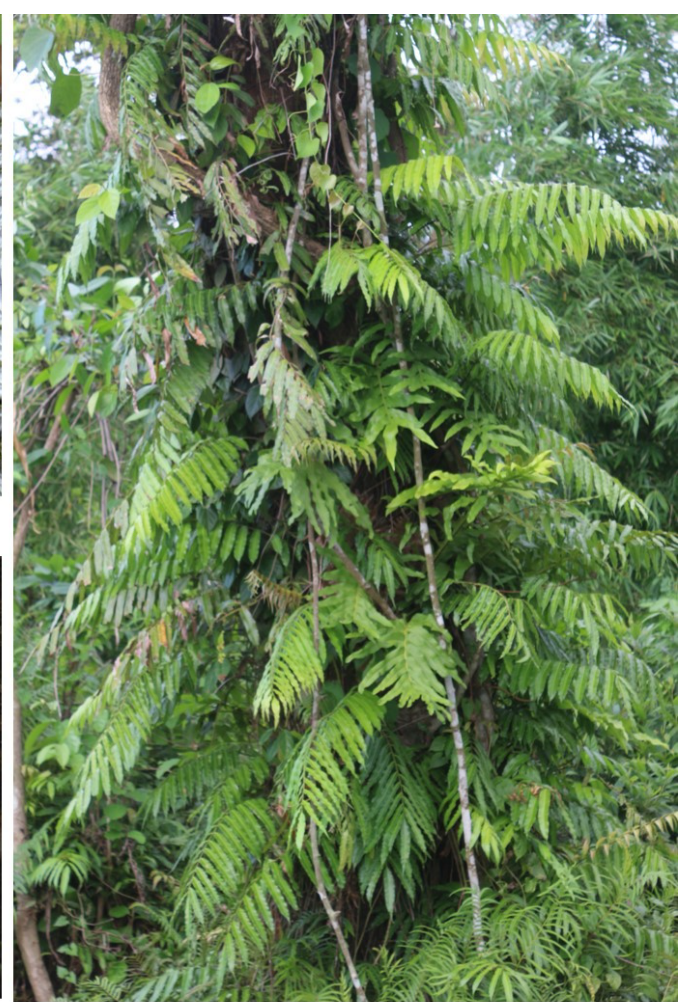

Stenochlaena palustris

Figure 1. Photographs of Aleuritopteris bicolor, Drynaria propinqua and Stenochlaena palustris

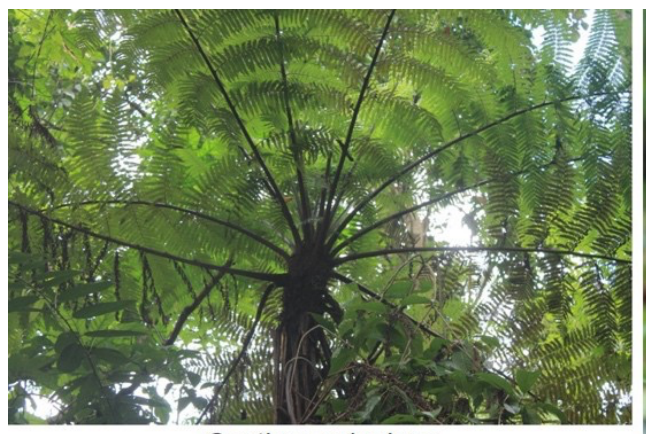

Cyathea spinulosa

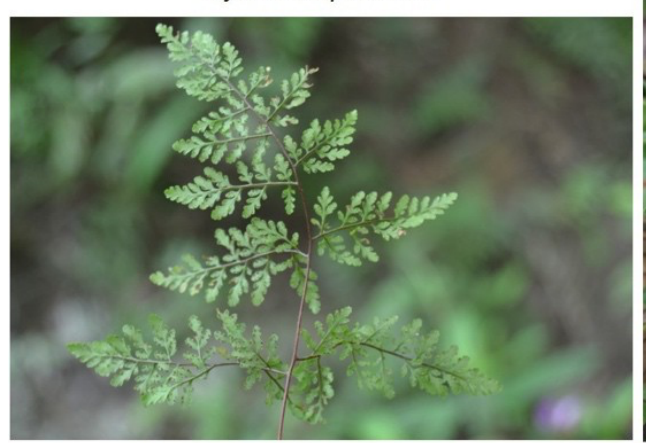

Oeosporangium tenuifolium

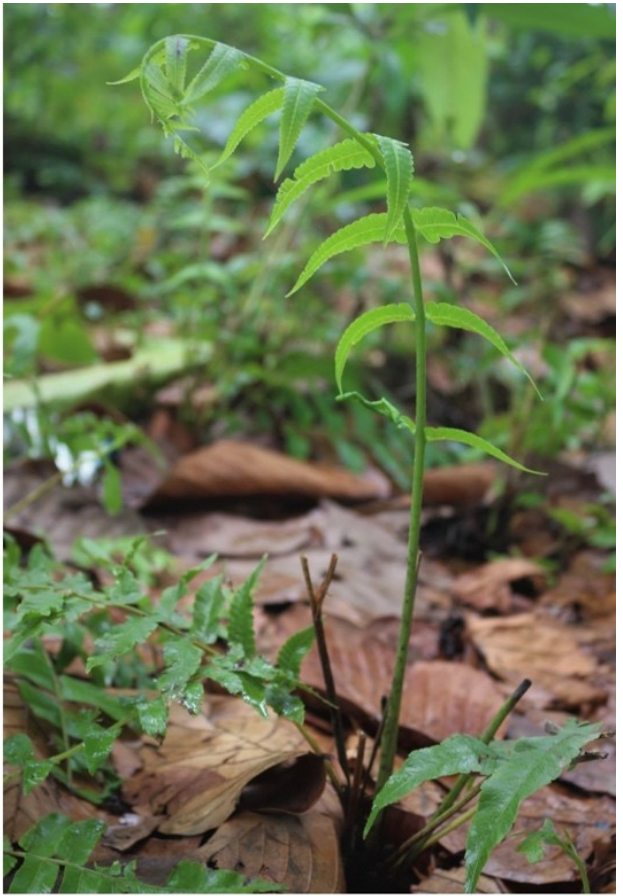

Diplazium esculentum

Figure 2. Photographs of Cyathea spinulosa, Oeosporangium tenuifolium and Diplazium esculentum 

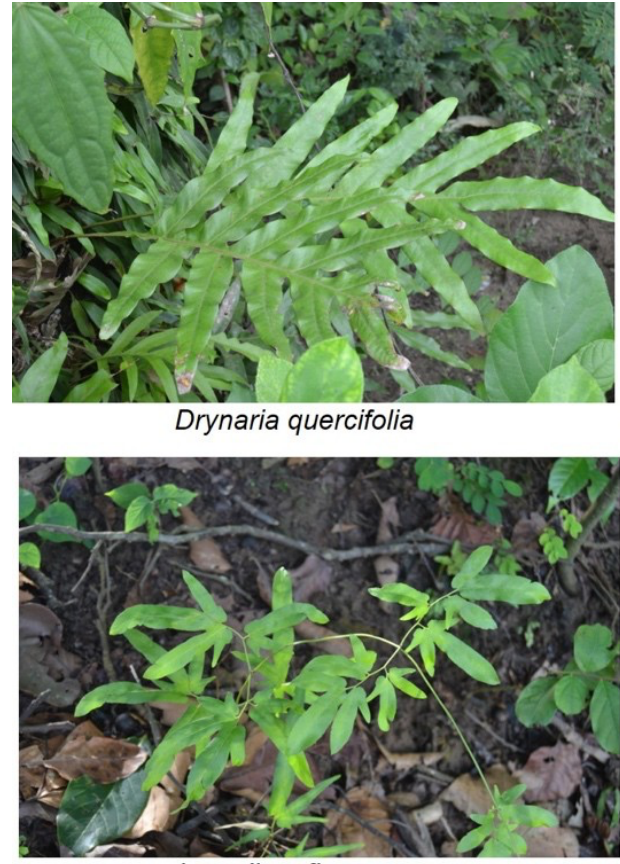

Lygodium flexuosum

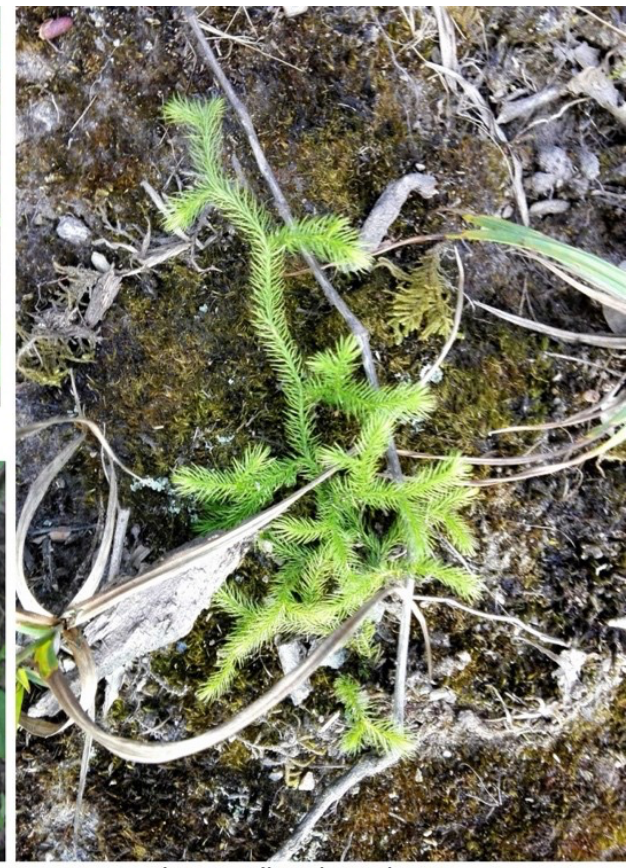

Lycopodium japonicum

Figure 3. Photographs of Drynaria quercifolia, Lygodium flexuosum and Lycopodium japonicum

This study revealed that there is a treasure of knowledge about the food and medicinal use of pteridophytes inNepal. Diplazium esculentum, Diplazium maximum, Dryopteris cochleata and Ophioglossum reticulatum are common edible species and Aleuritopteris albomarginata, Equisetum ramosissimum, Nephrolepis cordifolia and Tectaria coadunata are common medicinal species of pteridophytes. Although various studies have reported theiruse as traditional medicines, only a few studies have reported the dose, preparation method and duration of administration. In many published articles, these aspects of medicinal uses such as details of formulation process, dosage, duration, etc. are not reported. None of these studies report the possible toxicities or any precautions thatshould be taken when using them as vegetable or medicine. Ethnobotanical studies should report all these detailsabout the edible and medicinal plants. Similarly, these reports only mention the traditional use for the treatment of some diseases or symptoms, but there is no reliable data or scientific evidence on their effectiveness.

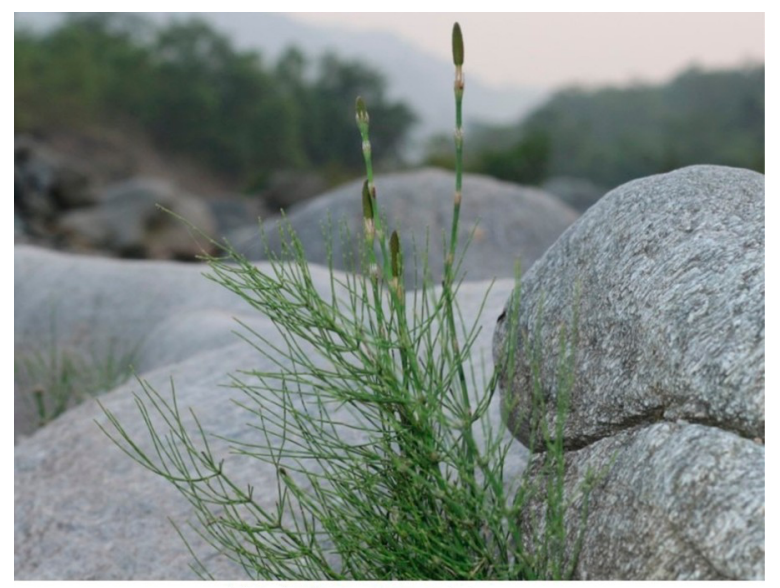

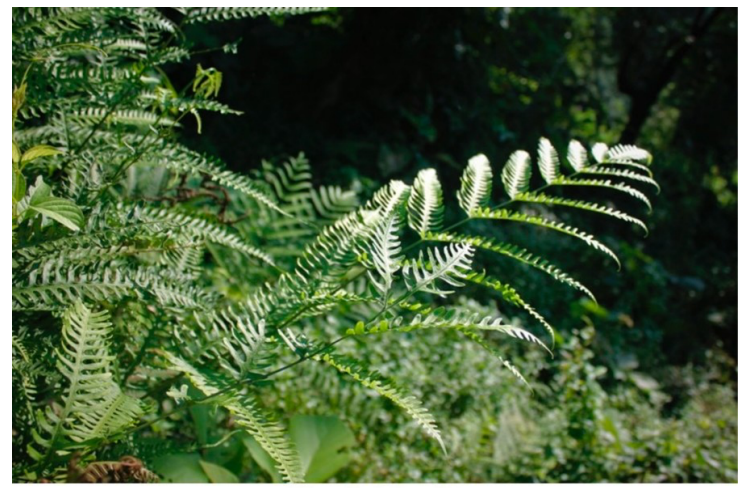

Pteris biaurita

Equisetum ramosisimum

Figure 4. Photographs of Equisetum ramosissimum and Pteris biaurita

There were some similarities and differences of use of edible and medicinal pteridophytes in Nepal and other countries. Pteridium aquilinum (L.) Kuhn is most common edible fern in China and Nigeria (Liu et al. 2012; Nwosu 2002). Several pteridophytes reported from Nepal such as Asplenium unilateral Lam., Blechnum orientale L., Coniogramme intermedia Hieron, Coniogramme denticulatoserrata (Hieron.) R.D. Dixit \& A. Das, Matteuccia intermedia C. Chr., Osmunda japonica Thunb., Pteris wallichiana J. Agardh, Thelypteris prolifera (Retz.) C.F. Reed, 
Woodwardia unigemmmata (Makino) Nakai are used as edible species in China. Similarly, Cyathea gigantean (Wall. ex Hook.) Holttum, Hypodematium crenatum (Forssk.) Kuhn, Leucostegia truncata (D. Don) Fraser-Jenk., Microsorum punctatum (L.) Copel., Pitryrogramma calomelanos (L.) Link., Psilotum nudum (L.) P. Beauv., Pteris cretica L., Pteris vittata L., Pyrrosia lanceolata (L.) Farw., Lygodium microphyllum (Cav.) R. Br., Huperzia phlegmaria (L.) Rothm., Huperzia squarrosa (G. Forst.) Trevis., Thelypteris interrupta (Willd.) K.Iwats, etc. are used as medicine in India and other parts of the world (Benjamin \& Manickam 2007, Benniamin 2011, Liu et al. 2012, Minarchenko et al. 2017). Some of the species like Athyrium atkinsoni, Athyrium strigillosum are consumed as vegetable only in Nepal as per our knowledge.

Edible and medicinal pteridophytes in Nepal were found to be distributed in different geographical regions. In the same genus, species were found to be distributed from low altitude to high altitude. For example, Athyrium atkinsoni is high altitude vegetable fern; $A$. strigillosum is an upper mid altitude vegetable fern. Diplazium esculentum is common vegetable fern in lower to upper mid altitude; $D$. kawakamii and $D$. spectabile are mid to upper mid altitude vegetable ferns; $D$. maximum is upper mid to higher altitude vegetable fern and $D$. stoliczkae is higher Himalayan vegetable species. Lygodium flexuosum and L. japonicum are low to mid altitude edible and medicinal ferns. Botrychium lanuginosum is a mid to higher altitude vegetable and medicinal fern; $B$. lunaria highaltitude to high Himalayan medicinal species and Botrychium multifidum is mid altitude to high Himalayan medicinal species. Ophioglossum reticulatum is low to mid altitude vegetable fern whereas $O$. petiolatum is an upper mid altitude vegetable and medicinal fern. Equisetum arvens is low altitude medicinal fern whereas E. ramossium is a mid to high altitude fern. Drynaria quercifolia is low altitude medicinal fern whereas $D$. propinqua ismid to upper mid altitude medicinal fern. Lepisorus bicolor is a mid to high altitude medicinal fern whereas $L$. mehrae and $L$. thunbergianus are upper mid to higher altitude medicinal fern. Adiantum capillusveneris, $A$. incisum and $A$. philippense are low to upper-mid altitude medicinal fern species; $A$. caudatum is low altitude medicinal fern species; $A$. venustum is upper-mid to high Himalayan medicinal fern species. Aleuritopteris albomarginata is upper- mid to higher altitude; $A$. anceps, $A$. bicolor and $A$. rufa are low to mid altitude medicinal species.

\section{Other uses as fermented/processed foods, cultural and ritual uses}

Dried fermented food (gundruk) is prepared from Ophioglossum reticulatum in Dolakha district (Shrestha \& Dhillion 2006). Tendrils of Dryopteris cochleata are used in making pickle (achar) (Acharya \& Acharya 2010).

Apart from the traditional use as food and medicinal value some pteridophytes Polystichum lentum (D. Don) Moore is used in animal bedding, Equisetum diffusum is used as fodder (Toba 1975). The fronds of Gleichenia gigantea is used as fuel and mulching (Joshi \& Joshi 2008). Lygodium japonicum (nagbeli) is used for religious purpose by Magar and Majhi especially in "Sauane sakranti" and in decoration of gates during weeding and other celebration, in decoration of Rato Machindra nath chariot of Patan (Kandel, 2020, Malla 2018). Stipe of Aleuritopteris bicolor isused to plug ear-piercing holes (Gyawali et al. 2021). Selaginella involvens (Sw.) Spring is used in Hindu ceremony "Satta nara" and in decoration of gate (Toba 1975) and women use spore powder as substitute to vermilion powder (sindoor) (Manadhar, 1996).

\section{Market value of pteridophytes in Nepal}

Literature survey reveals that at least 11 species of pteridophytes are sold in market as vegetable. Diplazium esculentum, Helminthostachys zeylanica and Ophioglossum reticulatum are sold in local markets of Western Nepal (Rajbhandari et al. 2015). Diplazium esculentum, Diplazium maximum, Diplazium spectabile, Diplazium stolickaze, Dryopteris cochleata, Dryoanthyrium boryanum, Polystichum squarrosum and Tectaria coadunata are sold in market in Central Nepal (Joshi et al. 2007, Joshi \& Siwakoti 2012, Shrestha 1988) and three species such as Dryopteris cochleata, Dryopteris splendens and Tectaria coadunata are sold in market in Eastern Nepal (Shrestha \& Rai 2012). They are important wild plants for income generation in rural area and for food security. Indigenous communities like Chepang also are involved in trade of ferns like Drypoteris cochleata for income (Luni et al. 2011). Spore of Lycopodium japonicum is traded from Nepal to China (Chapagain et al. 2021). Till now no practices of cultivating useful pteridophytes have been reported, neither the potential of wild species for supporting local economy is estimated. These pteridophytes are harvested from wild without any consideration of their sustainable use thus overharvesting is creating challenges for conservation. The edible ferns can also help to overcome nutritional deficiency especially in hilly areas (Chettri et al. 2018). 


\section{Threatened edible and medicinal pteridophytes in Nepal}

Many ferns of traditional use such as like Adiantum caudatum, Botrychium lunaria, Cyathea spinulosa, Helminthostachys zeylanica, Ophioglossum petiolatum and Stenochlaena palustris are threatened and rare in Nepal (Fraser-Jenkins et al. 2015, Fraser-Jenkins \& Kandel 2019). While considering ferns for medicinal value and food security, conservation about them is also important.

\section{Chemical constituents and biological activities of pteridophytes from Nepal}

Phenolic acids, flavonoids, steroids, and their derivatives are commonly reported from ferns of different families (Bohm \& Tryon 1967, Cao et al. 2017, Cerón-Carpio et al. 2019, Cui et al. 1993, Ueno et al. 1963). Phytoecdysteroids are also reported from various species of ferns (Cao et al. 2017, Dinan 2001, Hu et al. 2014). Huperzia is potential medicinal lycophyte of the Himalayas. The alkaloids present in the plant such as huperzine A and huperzine B are used in the treatment of various neurological diseases such as Alzheimer's disease (Yumkham et al. 2016). Huperzia squarrosa is important medicinal and ritual pteridophytes in Manipur, India this species is also traded in that area (Yumkham \& Singh 2013). Along with the 7 species of Huperzia, Huperzia squarrosa is also present in Nepal but no report of medicinal uses and trade of the species is recorded.

There have been only a very few studies related to chemical analysis and pharmacological activities of medicinal and edible ferns of Nepal. Thapa et al. (2013) analyzed the total phenolic content, total flavonoid content and antioxidative activity of extract of Diplazium stoliczkae. Shrestha et al. (2019) performed the phytochemical fingerprinting and bioactivity analysis of the twigs and rhizomes of Tectaria coadunata. Flavonoids such as procyanidins, eriodoctyl glycosides and luteolin glycosides were identified as major compounds. The extracts alsoshowed antioxidant and cholinesterase and tyrosinase inhibitory activities.

Pteridophytes used in Nepal for edible and medicinal purposes should be studied in detail for their major chemical constituents and biological activities. Identification of major compounds can help in designing protocols for the identification and quality control of the marketed species. Both the extracts and isolated compounds should be studied to evaluate their biological activities and to elucidate the mechanisms of actions. Pharmacological studies based on traditional uses can support to provide scientific evidence for their traditional uses as medicines.

\section{Safety and toxicity concerns of pteridophytes}

Mostly, young leaves (fronds) of ferns are consumed as vegetables and rhizomes and leaves are used as traditional medicines. Many fern species, such as Bracken fern (Pteridium aquilinum) are reported to be toxic and carcinogenic due to presence of a carcinogenic compound, ptaquiloside (Potter \& Baird 2000, Rasmussen et al. 2013, Virgilio et al. 2015). Ptaquiloside has also been reported from the milk of cows, sheeps and goats grazing on Pteridium aquilinum (Virgilio et al. 2015). Great care should be taken for proper identification of wild fern species when collecting for food and medicinal purposes. Similarly, the processing of these species for their use as food and medicines should be properly documented. Any toxicities observed should be properly documented and suchinformation related to possible toxicities should be properly communicated to local people.

\section{Conclusions}

In this review, the available ethnobotanical information about the traditional knowledge of medicinal and edible uses of pteridophytes in Nepal is compiled. Many species which are used for medicinal purposes were also used forfood values. However, there has not been any ethnopteridological study in Nepal that deals specifically about the traditional uses of ferns and fern allies. The knowledge of useful pteridophytes and their biodiversity are neglected in Nepal and available knowledge is also affected by socioeconomic changes in communities, sharing of knowledge through generations, etc. On the other hand, only a very few scientific studies have been carried out on the chemical constituents and pharmacological activities of pteridophytes collected in Nepal. There are no studies reported from Nepal regarding the safety and toxicity of commonly consumed pteridophytes which needs urgent attention. Thenutritional values of edible species should be studied and for the medicinally used species, there should be extensive studies to identify the active chemical constituents and their pharmacological activities. Only a few species are sold in the markets which are mostly collected from wild. The unsustainable collection practices lead to the decrease innatural population, thus there should be initiatives for conservation and cultivation in collaboration with communities. Such practices can help in income generation and economic empowerment of local communities. The multidisciplinary collaboration is necessary for performing scientific studies related to useful pteridophytes of Nepal regarding their biodiversity conservation, sustainable utilization, and product developments. 


\section{Declarations}

List of abbreviations: Not applicable.

Ethics approval and consent to participate: Not applicable.

Consent for publication: This paper does not include any individual person's data and further permission forpublication is not required.

Availability of data and materials: The data was not deposited in public repositories.

Conflict of interests: The authors declare that they have no competing interests.

Funding: This study did not receive any specific grant from funding organizations.

Authors' contribution: Both authors conceived the idea, wrote the initial version of the manuscript, and revisedthe manuscript and approved the final version of the manuscript.

\section{Acknowledgements}

We would like to thank Mr. Dhan Raj Kandel, Research Officer, National Herbarium and Plant Laboratories, Godawari, Lalitpur, Nepal for useful discussions.

\section{Literature cited}

Acharya KP, Acharya R. 2010. Eating From the Wild: Indigenous Knowledge on Wild Edible Plants in Parroha Vdc of Rupandehi District, Central Nepal. International Journal of Social Forestry 3(1):28-48.

Adhikari M, Thapa R, Kunwar RM, Devkota HP, Poudel P. 2019. Ethnomedicinal Uses of Plant Resources in the Machhapuchchhre Rural Municipality of Kaski District, Nepal. Medicines 6(2):69.

Ale R, Raskoti BB, Shrestha K. 2009. Ethnobotanical Knowledge of Magar Community in Siluwa VDC, Palpa District, Nepal. Journal of Natural History Museum 24:58-71.

Ambu G, Chaudhary RP, Mariotti M, Cornara L. 2020. Traditional Uses of Medicinal Plants by Ethnic People in the Kavrepalanchok District, Central Nepal. Plants 9(6):759.

Aryal KP, Berg Å, Ogle B. 2009. Uncultivated plants and livelihood support - A case study from the chepang people of Nepal. Ethnobotany Research and Applications 7:409-422.

Benjamin A, Manickam VS. 2007. Medicinal pteridophytes from the Western Ghats. Indian Journal of Traditional Knowledge 6(4):611-618.

Benniamin A. 2011. Medicinal ferns of north-eastern India with special reference to Arunachal Pradesh. Indian Journal of Traditional Knowledge 10(3):516-522.

Bhagat IM, Shrestha S. 2010. Fern and Fern-Allies of Eastern Terai, Nepal. Our Nature 8(1):359-361.

Bhatt MD, Adhikari YP, Kunwar RM. 2021. Ethnomedicinal values of weeds in Kanchanpur district, far-western Nepal. Ethnobotany Research and Applications 21:1-19.

Bhattarai KR. 2020. Ethnobotanical survey on plants used in Mai Municipality of Ilam district, eastern Nepal. Banko Janakari 30(2):11-35.

Bhattarai KR, Vetaas OR, Grytnes JA. 2004. Fern species richness along a central Himalayan elevational gradient, Nepal. Journal of Biogeography 31(3):389-400.

Bhattarai KR, Khadka MK. 2016. Ethnobotanical survey of medicinal plants from Ilam District, East Nepal. Our Nature 14(1):78-91.

Bhattarai NK. 1989. Traditional phytotherapy among the sherpas of helambu, Central Nepal. Journal of Ethnopharmacology 27(1-2):45-54.

Bhattarai NK. 1992. Medical Ethnobotany in the Karnali Zone, Nepal. Economic Botany 46(3):257-261.

Bohm BA, Tryon RM. 1967. Phenolic Compounds in Ferns: I. a Survey of Some Ferns for Cinnamic Acid and Benzoic Acid Derivatives. Canadian Journal of Botany 45(5):585-593.

Budha-Magar S, Bhandari P, Ghimire SK. 2020. Ethno-medicinal survey of plants used by magar (Kham) community, Rolpa district, western Nepal. Ethnobotany Research and Applications 19(18):1-29. 
Cao H, Chai TT, Wang X, Morais-Braga MFB, Yang JH, Wong FC, Wang R, Yao H, Cao J, Cornara L, Burlando B, WangY, Xiao J, Coutinho HDM. 2017. Phytochemicals from fern species: potential for medicine applications. Phytochemistry Reviews 16(3). Springer Netherlands.

Cerón-Carpio AB, Pérez-García B, Monribot Villanueva JL, Kiel-Martínez AL, Espinosa-Matias S, Guerrero-Analco JA, Mehltreter K 2019. Chemical composition and micromorphological structure of cuticular leaf waxes of eight tropical fern species of Mexico. Biochemical Systematics and Ecology 85:13-20.

Chapagain A, Wang June, Che-Lan L, Shah S, Pyakure D. 2021. Himalayan Medicinal Plant Species Traded from Nepal to China. In Integrating Biological Resources for Prosperity. Edited by Siwakoti M, Mandal TN, Rai SK, Rai SK, Gautam TP, Aryal HP \& Limbu KP. Botanical Society of Nepal, Nepal Biological Society and Department of Plant Resources, Kathmandu, Nepal.

Chettri S, Manivannan S, Muddarsu VR. 2018. Nutrient and Elemental Composition of Wild Edible Ferns of the Himalaya. American Fern Journal 108(3):95-106.

Christenhusz MJ, Byng JW. 2016. The number of known plants species in the world and its annual increase. Phytotaxa 261(3):201-217.

Cui CB, Tezuka Y, Yamashita H, Kikuchi T, Nakano H, Tamaoki T, Park JH. 1993. Constituents of a Fern, Davallia mariesii Moore. V.1,2) Isolation and Structures of Davallin, a New Tetrameric Proanthocyanidin, and Two New Phenolic Glycosides. Chemical and Pharmaceutical Bulletin 41(9):1491-1497.

Dangol DR. 2008. Traditional Uses of Plants of Commonland Habitats. Journal of the Institute of Agriculture and Animal Science 29:71-78.

Dhami N. 2008. Ethnomedicinal uses of plants in Western Terai of Nepal: a case study of Dekhatbhuli VDC of Kanchanpur district. In Medicinal Plants in Nepal: An Anthology of Contemporary Research. Edited by Jha PK, Karmacharya SB, Chettri MK, Thapa CB, Shrestha BB. Ecological Society (ECOS), Kathmandu, Nepal.

Dinan L. 2001. Phytoecdysteroids: Biological aspects. Phytochemistry 57(3):325-339.

Fraser-Jenkins CR, Kandel, DR, Pariyar S. 2015. Ferns and Fern-allies of Nepal (Vol. 1). National Herbarium and Plant Laboratories, Department of Plant Resources, Ministry of Forests and Soil Conservation, Nepal.

Fraser-Jenkins CR, Kandel DR. 2019. Ferns and Fern-allies of Nepal (Vol. 2). National Herbarium and Plant Laboratories, Department of Plant Resources, Ministry of Forests and Soil Conservation, Nepal.

Gurung VL. 1979. Medicinal Ferns of Nepal. J. Nep. Pharm. Associ. 7:67-76.

Gyawali I, Bhattarai S, Khanal S. 2021. Ethnobotanical, Phytchemical, and Allelopathic Potentinal of Traditional Medicinal Plants. Turkish Journal of Agriculture - Food Science and Technology 9(1):224-233.

Ho R, Teai T, Bianchini JP, Lafont R, Raharivelomanana P. 2010. Ferns: From traditional uses to pharmaceutical development, chemical identification of active principles. In Working with Ferns: Issues and Applications.

Hu J, Shi X, Mao X, Li H, Chen J, Shi J. 2014. Ecdysteroids from the ethanol extract of Diplopterygium rufopilosum. Phytochemistry Letters 8(1):73-76.

Joshi AR, Joshi K. 2009. Documentation of Wetland Plant Diversity with Indigenous Uses in Nepal - a Case Study of Some Wetlands of Two Valleys (Kathmandu and Pokhara). Ethnobot 21:11-17.

Joshi K, Joshi AR. 2008. Ethnobotanical Studies on Some Lower Plants of the Central Development Region, Nepal. Ethnobotanical Leaflets 12:832-840.

Joshi K, Joshi R, Joshi AR. 2011. Indigenous knowledge and uses of medicinal plants in Macchegaun, Nepal. Indian Journal of Traditional Knowledge 10(2):281-286.

Joshi NP. 2014. Utilization opattern and conservation status of plant resources of Makawanpu district, Nepal. Phd Dissertation, Tribhuvan University.

Joshi N, Siwakoti M. 2012. Wild Vegetables Used by Local Community of Makawanpur District and Their Contribution to Food Security and Income Generation. Nepal Journal of Science and Technology 13(1):59-66.

Joshi N, Kehlenbeck K, Maass BL. 2007. Traditional, neglected vegetables of Nepal: Their sustainable utilization for 
meeting human needs. Conference on International Agricultural Research for Development.

Joshi N, Siwakoti M, Kehlenbeck K. 2015. Wild vegetable species in Makawanpur district, central Nepal: Developing a priority setting approach for domestication to improve food security. Economic Botany 69(2):161-170.

Kandel DR. 2020. Pteridophytes of Nepal. In Plant Diversity in Nepal Edited by Siwakoti M, Jha PK, Rajbhandary S, Rai SK. Botanical Society of Nepal, Kathmandu, pp. 71-82.

Kandel DR, Fraser-Jenkins CR. 2020. Ferns and Fern-allies of Nepal (Vol. 3). National Herbarium and Plant Laboratories, Department of Plant Resources, Ministry of Forests and Soil Conservation, Nepal.

Kunwar RM, Chowdhary CL, Bussmann RW. 2008. Diversity, Utilization and Management of Medicinal Plants in Baitadi and Darchula Districts, Far West Nepal. The Initiation 2(1):157-164.

Liu Y, Wujisguleng W, Long C. 2012. Food uses of ferns in China: A review. Acta Societatis Botanicorum Poloniae 81(4):263-270.

Luitel DR, Rokaya MB, Timsina B, Münzbergová Z. 2014. Medicinal plants used by the Tamang community in the Makawanpur district of central Nepal. Journal of Ethnobiology and Ethnomedicine 10(1):1-11.

Luni P, Maharjan K, Joshi N. 2011. Forest and Food Security of Indigenous People: A Case of Chepangs in Nepal. Journal of International Development and Cooperation 17(1):113-135.

Malla B, Chhetri RB. 2009. Indigenous Knowledge on Ethnobotanical Plants of Kavrepalanchowk District. Kathmandu University Journal of Science, Engineering and Technology 5(2):96-109.

Malla B. 2018. Ethnobotanical study on medicinal plants in Parbat district of western Nepal. Phd Dissertation, Kathmandu University.

Malla B, Gauchan DP, Chhetri RB. 2015. An ethnobotanical study of medicinal plants used by ethnic people in Parbat district of Western Nepal. Journal of Ethnopharmacology 165:103-117.

Manandhar NP. 1986. Ethnobotany of jumla district, Nepal. International Journal of Crude Drug Research 24(2):8189.

Manandhar NP. 1990. Medico Botany of gorkha district, Nepal -an elucidation of medicinal plants. InternationalJournal of Crude Drug Research 28(1):17-25.

Manandhar NP. 1993. Ethnobotanical note on folk lore remedies of Baglung district Nepal. Contributions toNepalese Studies 20(2):183-196.

Manandhar NP. 1996. Ethnobotanical observations on ferns and fern allies of Nepal. Journal of Economic Taxonomic Botany 12:414-422.

Manandhar NP. 1995a. An inventory of some herbal drugs of Myagdi district, Nepal. Economic Botany 49(4):371-379.

Manandhar NP. 1995b. A survey of medicinal plants of Jajarkot district, Nepal. Journal of Ethnopharmacology48(1):1-6.

Manandhar NP. 2002. Plants and People of Nepal. Timber Press, Inc, Portland.

Minarchenko V, Tymchenko I, Dvirna T, Makhynia L. 2017. A review of the medicinal ferns of Ukraine. Scripta Scientifica Pharmaceutica 4(1):7.

Nwosu MO. 2002. Ethnobotanical Studies on Some Pteridophytes of Southern Nigeria. Economic Botany 56(3):255259.

Ojha R, Niroula B. 2021. Inventory of Ferns and Fern Allies of Raja-Rani Wetland and Adjoining Forest, Eastern Nepal. Journal of Plant Resources 19:55-61.

Pradhan SP, Chaudhary RP, Sigdel S, Pandey BP. 2020. Ethnobotanical knowledge of khandadevi and gokulganga rural municipality of ramechhap district of nepal. Ethnobotany Research and Applications 20:1-32.

Potter DM, Baird MS. 2000. Carcinogenic effects of ptaquiloside in bracken fern and related compounds. BritishJournal of Cancer 83:914-20. 
Rai R, Singh NB. 2015. Medico-ethnobiology in rai community: A case study from Baikunthe Village Development Committee, Bhojpur, Eastern Nepal. Journal of Institute of Science and Technology 20(1):127-132.

Rajbhandari KR, Thapa Magar MS, Kandel DR, Khanal C. 2016. Plant Resources of Kailali, West Nepal. District Plant Resources Office, Kailali, Nepal.

Rana SK, Oli PS, Rana HK. 2015. Traditional botanical knowledge (TBK) on the use of medicinal plants in Sikles area, Nepal. Asian Journal of Plant Science and Research 5(11):8-15.

Ranil RHG, Bussmann RW. 2021. Potential uses of lycophytes and ferns in Sri Lanka : an ethnopteridological perspective. Ethnobotany Research and Applications 21(36):1-11.

Rasmussen LH, Schmidt B, Sheffield E. 2013. Ptaquiloside in bracken spores from Britain. Chemosphere 90:25392541.

Rijal A. 2011. Surviving on Knowledge: Ethnobotany of Chepang community from midhills of Nepal. Ethnobotany Research and Applications 9:181-215.

Rokaya MB, Münzbergová Z, Timsina B. 2010. Ethnobotanical study of medicinal plants from the Humla district of western Nepal. Journal of Ethnopharmacology 130(3):485-504.

Sarker SK, Hossain ABME. 2009. Pteridophytes of greater mymensingh district of Bangladesh used as vegetables and medicines. Bangladesh Journal of Plant Taxonomy 16(1):47-56.

Shrestha I, Joshi N. 1993. Medicinal plants of the lele village of Lalitpur district, Nepal. International Journal of Pharmacognosy 31(2):130-134.

Shrestha, P. 1988. Contibutions to the Ethnobotany of the Tamangs of Kathmandu Valley. Contribution to Nepalese Studies 15(2):247-267.

Shrestha PM, Dhillion SS. 2006. Diversity and traditional knowledge concerning wild food species in a locally managed forest in Nepal. Agroforestry Systems 66(1):55-63.

Shrestha S, Rai SK. 2012. Survey of marketable vegetables and edible fruits in Dharan, eastern Nepal. Nepalese Journal of Biosciences 2:134-147.

Shrestha SS, Sut S, Marco SB Di, Zengin G, Gandin V, Franco M De, Pant DR, Mahomoodally MF, Dall'Acqua S, Rajbhandary S. 2019. Phytochemical Fingerprinting and In Vitro Bioassays of the Ethnomedicinal Fern Tectaria coadunata (J. Smith) C. Christensen from Central Nepal. Molecules 24: 4457.

Singh AG. 2015. Survey of Some Medicinally Important Leafy Vegetables in Rupandehi District of Western Nepal. International Journal of Applied Sciences and Biotechnology 3(1):111-118.

Singh AG, Hamal JP. 2013. Traditional Phytotherapy of Some Medicinal Plants Used by Tharu and Magar Communites of Western Nepal, Against Dermatological Disorders. Scientific World 11(11):81-89.

Sureshkumar J, Silambarasan R, Bharati KA, Krupa J, Amalraj S, Ayyanar M. 2018. A review on ethnomedicinally important pteridophytes of India. Journal of ethnopharmacology 219:269-287.

Tamang R, Thakur C, Koirala D, Chapagain N. 2017. Ethno-medicinal Plants Used by Chepang Community in Nepal. Journal of Plant Resources 15(1):21-30.

Thakur C, Rajbhandary S. 2018. Fern and Fern Allies of Panchase Protected Forest, Central Nepal. Journal of Plant Resources 16(1):39-45.

Thapa LB, Dhakal TM, Chaudhary R. 2014. Wild Edible Plants Used by Endangered \& Indigenous Raji Tribe in Western Nepal. International Journal of Applied Sciences and Biotechnology 2(3):243-252.

Thapa R, Poudel P, Poudel A, Devkota HP, Jamarkattel-Pandit N. 2013. Antioxidative Activity, Total Phenolic and Flavonoid Contents of Selected Nepalese Medicinal Plants. Indian Journal of Pharmacology 45:S184-S184.

Thapa S. 2012. Medico-ethnobotany of Magar Community in Salija VDC of Parbat District, Central Nepal. Our Nature 10:176-190.

Toba S. 1975. Plant names in Khaling: a study in ethnobotany and village economy. Kailash 3:147-170. 
Tuladhar DY. 2002. Medicinal Ferns of Nepal. In The Himalayan plants, can they save us? Proceeding of Nepal-Japan joint symposium on conservation and utilization of Himalayan medicinal resources. Edited by Watanabe T, Takano A, Bista M, Saiju H. Society for the Conservation and Development of Himalayan Medicinal Resources (SCDHMR).

Ueno A, Oguri N, Hori K, Saiki Y, Harada T. 1963. Pharmaceutical Studies on Ferns. XVIII. Yakugaku Zasshi 83(4):420-422.

Uprety Y, Asselin H, Boon E, Yadav S, Shrestha K. 2010. Indigenous use and bio-efficacy of Rasuwa district, central Nepal. Journal of Ethnobiology and Ethnomedicine 6(3):1-10.

Uprety Y, Poudel RC, Asselin H, Boon E. 2011. Plant biodiversity and ethnobotany inside the projected impact area of the Upper Seti Hydropower Project, Western Nepal. Environment, Development and Sustainability 13(3):463-492.

Uprety Y, Poudel RC, Shrestha KK, Rajbhandary S, Tiwari NN, Shrestha UB, Asselin H. 2012. Diversity of use and local knowledge of wild edible plant resources in Nepal. Journal of Ethnobiology and Ethnomedicine 8(16):1-15.

Virgilio A, Sinisi A, Russo V, Gerardo S, Santoro A, Galeone A, Taglialatela-Scafati O, Roperto F. 2015. Ptaquiloside, the Major Carcinogen of Bracken Fern, in the Pooled Raw Milk of Healthy Sheep and Goats: An Underestimated, Global Concern of Food Safety. Journal of Agricultural and Food Chemistry 63:4886-4892.

Watanabe M, Miyashita T, Devkota HP. 2021. Phenolic compounds and ecdysteroids of Diplazium esculentum (Retz.) Sw. (Athyriaceae) from Japan and their chemotaxonomic significance. Biochemical Systematics and Ecology 94:104211.

Yumkham SD, Singh PK. 2013. Study on Uses and Trading of Huperzia squarrosa (G. Forst.) Trev. (Lycopodiaceae) in Manipur, India. Ethnobotany Research and Applications 11:153-161.

Yumkham SD, Chakpram L, Salam S, Bhattacharya MK, Singh PK. 2016. Edible ferns and fern-allies of North East India: a study on potential wild vegetables. Genetic resources and crop evolution 64(3):467-477. 